PERM JOURNAL OF PETROLEUM AND MINING ENGINEERING

ВЕСТНИК ПНИПУ. ГЕОЛОГИЯ. НЕФТЕГАЗОВОЕ И ГОРНОЕ ДЕЛО

ISSN 2224-9923

Volume / Toм 20 №1 2020

http://vestnik:pstu.ru/ge

UDC 622.276:553.98.044

Article / Статья

(C) PNRPU / ПНИПУ, 2020

\title{
DEVELOPING A STATISTICAL MODEL OF OIL AND GAS POTENTIAL PREDICTION BY GAS SHOWINGS IN THE VERKHNEKAMSKOYE DEPOSIT STRATA OF POTASSIUM AND MAGNESIUM SALTS
}

\author{
Vladislav I. Galkin, Oleg A. Melkishev, Stanislav V. Varushkin, Segey S. Andreiko ${ }^{1}$, Tamara A. Lialina ${ }^{1}$
}

Perm National Research Polytechnic University (29 Komsomolskiy av., Perm, 614990, Russian Federation)

${ }^{1}$ Mining Institute of Ural Branch of the Russian Academy of Sciences (78a Sibirskaya st., Perm, 614007, Russian Federation)

\section{РАЗРАБОТКА СТАТИСТИЧЕСКОЙ МОДЕЛИ ПРОГНОЗА НЕФТЕГАЗОНОСНОСТИ ПО ГАЗОВЫДЕЛЕНИЯМ В ТОЛЩЕ ВЕРХНЕКАМСКОГО МЕСТОРОЖДЕНИЯ КАЛИЙНО-МАГНИЕВЫХ СОЛЕЙ}

\section{В.И. Галкин, О.А. Мелкишев, С.В. Варушкин, С.С. Андрейко', Т.А. Лялина'}

Пермский национальный исследовательский политехнический университет (614990, Россия, г. Пермь, Комсомольский проспект, 29) ${ }^{1}$ Горный институт Уральского отделения Российской академии наук - филиал Пермского федерального исследовательского центра Уральского отделения Российской академии наук (614007, Россия, г. Пермь, Сибирская, 78a)

Received / Получена: 01.10.2019. Accepted / Принята: 10.01.2020. Published / Опубликована: 02.03.2020

Key words:

oil and gas potential prediction, gas content of salts, gas-dynamic effects, probabilistic and statistical models, probability,

Verkhnekamskoye deposit of potassium and magnesium salts, potassium Krai.
Ключевые слова: трогноз нестегазоносности, газоносность солей, газодинамические явления, вероятностно-статистические модели, вероятность Верхнекамское месторождение калийно-магниевых солей, Пермский край.

\begin{abstract}
The Verkhnekamskoye deposit of potassium and magnesium salts is located in Solikamsk depression within Pre-Urals foreland basin. There is a salt deposit in the near-surface section, with a number of oil and gas deposits below it.

The gas-oil ratio is known to be central to the process of gas showings during drilling of geological exploration wells and initiation of gas-dynamic phenomena at underground operations. For this purpose, all evidence on gas showings recorded when drilling salt exploration wells at the Verkhnekamskoye potash deposit was collected, as reflected in archival data and reports on prospect evaluation surveys. The findings were summarized and used to build a probabilistic and statistical model of oil and gas potential prediction.

This study considers 18 characteristics of 374 wells, related to the thickness of salt productive formations and their quantity. This study considers 18 characteristics of 374 wells, related to the thickness of salt productive for
The characteristics were compared using the Student's t-test and Pearson's chi-squared test $\left(\chi^{2}\right)$.

The characteristics were compared using the Student's t-test and Pearson's chi-squared test $\left(\chi^{2}\right)$.
This dependence was used to calculate probability values $P_{\mathrm{p}}\left(Z_{\mathrm{m}}\right)$ for all 856 studied salt exploration wells.

At the first stage, individual one-dimensional probabilistic models of gas potential prediction were built. The obtained individual probabilities served the basis for obtaining a discriminant function $\left(Z_{\mathrm{m}}\right)$ to predict the gas potential in the salt massive.

The obtained values of $Z_{\mathrm{m}}$ discriminant function were used to build a regression model of oil and gas potential prediction $P_{\mathrm{p}}\left(Z_{\mathrm{m}}\right)$

Following this dependency, $P_{\mathrm{p}}\left(Z_{\mathrm{m}}\right)$ values were calculated for all 856 studied wells drilled for exploration and prospecting operations for the purpose of salt extraction.

The average value ( \pm standard deviation) of the probability for the class within the outline of the oil and gas zone was $0.510 \pm 0.068$ unit fractions. For the class outside the oil and gas zone, the average value was $0.490 \pm 0.070$ unit fractions. The obtained models enable constructing gas-show prediction schemes and an oil and gas potential prediction scheme for the Verkhnekamskoye potash deposit.
\end{abstract} Верхнекамское месторождение калийно-магниевых солей расположено в пределах Предуральского краевого прогиба на территории Соликамской депрессии. В верхней части разреза находится соляная залежь, а ниже ее множество месторождений нефти и газа.

Известно, что газовый фактор играет основную роль в процессе протекания газовыделений при бурении геолого-разведочных скважин и инициирования газодинамических явлений при подземных горных работах. Для этого были собраны все сведения о газовыделениях, зафиксированных при бурении солеразведочных скважин на территории Верхнекамского месторождения калийных солей, приведенные в архивных данных и отчетах о поисково-оценочных работах. Они были обобщены и использованы для построения вероятностно-статистической модели прогноза нефтегазоносности.

В работе рассмотрено 18 характеристик по 374 скважинам, связанных с мощностью продуктивных пластов солей и их количеством. Сопоставление характеристик производилось при помощи $t$-критерия Стьюдента и критерия Пирсона $\chi^{2}$.

На первом этапе строились индивидуальные одномерные вероятностные модели прогноза газоносности. Полученные индивидуальные вероятности являлись основой для получения дискриминантной функции $\left(Z_{\mathrm{m}}\right)$ для прогнозирования газоносности в толше солей.

Полученные значения дискриминантной функции $Z_{\mathrm{M}}$ использовались для построения регрессионной модели прогноза нефтегазоносности $P_{\mathrm{H}}\left(Z_{\mathrm{v}}\right)$.

прогноза нефтегазоносности $P_{\text {н }}\left(Z_{\mathrm{M}}\right)$.

По данной зависимости были вычислены значения вероятности $P_{\mathrm{H}}\left(Z_{\mathrm{M}}\right)$ по Средне значение ( \pm стандартное отклонение) вероятности для класса в контуре нефтегазоносности составило $0,510 \pm 0,068$ доли ед. Для класса вне контура нефтегазоносности среднее значение составило $0,490 \pm 0,070$ доли ед. Полученные модели позволяют построить схемы прогноза газопроявлений и схему прогноза нефтегазоносности в пределах Верхнекамского месторождения калийных солей.

\footnotetext{
Vladislav I. Galkin (Author ID in Scopus: 55418067700) - Doctor in Geology and Mineralogy, Professor, Head of the Department of Oil and Gas Geology (tel.: +007342 21980 00, e-mail: Vgalkin@pstu.ru).

Oleg A. Melkishev (Author ID in Scopus: 55531674700) - PhD in Engineering, Associate Professor at the Department of Oil and Gas Geology (tel.: +007 3422198411 , e-mail: Melkishev@pstu.ru). The contact person for correspondance.

Stanislav V. Varushkin - PhD student at the Department of Oil and Gas Geology (tel.: +007 34221980 00, e-mail: Stanislav.Varushkin2@lp.lukoil.com).

Segey S. Andreiko (Author ID in Scopus: 119301) - Doctor in Engineering, Professor, Head of Laboratory of Geotechnological Processes and Mine Gas Dynamics (tel.: +007342 2167502 , e-mail: ssa@mi-perm.ru).

Tamara A. Lialina (Author ID in Scopus: 569077) - Engineer (tel.: +007 34221675 02, e-mail: lyalina@mi-perm.ru).
}

Галкин Владислав Игнатьевич - доктор геолого-минералогических наук, професcop, заведующий кафедрой геологии нефти и газа (тел.: +007 219 8000 , e-mail: Vgalkin $@$ pstu.ru) Мелкишев Олег Александрович - кандидат технических наук, доцент кафедры геологии нефти и газа (тел.: +007 3422198411 , e-mail: Melkishev@pstu.ru). Контактное лицо для переписки.

Варушкин Станислав Владимирович - аспирант кафедры геологии нефти и газа (тел.: +007 219 80 00, e-mail: Stanislav.Varushkin2@1p.lukoil.com), Андрейко Сергей Семенович - доктор технических наук, профессор, заведующий лабораторией геотехнологических процессов и рудничной газодинамики (тел.: +007342 21675 02, e-mail: ssa@mi-perm.ru).

Лялина Тамара Александровна - инженер (тел.: +007 34221675 02, e-mail: lyalina@mi-perm.ru). 


\section{Introduction}

The Verkhnekamskoye deposit of potassium and magnesium salts (VKDMS) is located in Solikamsk depression within Pre-Urals foreland basin. There is a salt deposit in the near-surface section, with a number of oil and gas deposits below it. This area is of great interest when studying oil and gas content distribution in the section [1-10].

The gas-oil ratio is known to be central to the process of gas showings in drilling geological exploration wells and to gas-dynamic effects in the underground operations. For this purpose, all evidence on gas showings recorded during the salt exploration wells drilling at the Verkhnekamskoye potash deposit was collected, as reflected in archival data and reports on prospect evaluation surveys. The findings were summarized and used to build a probabilistic and statistical model of oil and gas potential prediction.

The possibilities of geological and mathematical model-building to address various geological problems are given in [11-14]. We applied the methods of mathematical statistics and probability theory to one-dimensional and multidimensional linear statistical model-building. These methods are in details described in works of both Russian and foreign authors [15-30].

\section{Development of Gas Potential Prediction Models for the VKDMS Strata}

Initially, for the development of gas showings prediction models, the average values for the areas [31-45] with the gas showings (Class 1) were compared with those for the areas with no gas showings observed (Class 2). For this we used a training sample of 374 wells (Fig. 1).

The analysis was conducted using various statistical criteria by the following characteristics: $M_{\text {ors }}$ is the thickness of the overlying rock salt, $\mathrm{M}_{\text {potash }}$ is the potash layer thickness (from the $1^{\text {st }}$ potash layer to the bottom of salts), $\mathrm{N}_{\mathrm{f}}$ is the quantity of formations in the section, $\mathrm{M}_{\mathrm{s}}$ is the thickness of salt stratum, $\mathrm{M}_{\mathrm{fK}}$ is the thickness of formation $\mathrm{K}, \mathrm{M}_{\mathrm{fl}}$ is the thickness of formation $\mathrm{I}, \mathrm{M}_{\mathrm{fZ}}$ is the thickness of formation $\mathrm{Z}, \mathrm{M}_{\mathrm{fZh}}$ is the thickness of formation $\mathrm{Zh}, \mathrm{M}_{\mathrm{fE}}$ is the thickness of formation $\mathrm{E}, \mathrm{M}_{\mathrm{fD}}$ is the thickness of formation $\mathrm{D}$, $\mathrm{M}_{\mathrm{fG}}$ is the thickness of formation $\mathrm{G}, \mathrm{M}_{\mathrm{fV}}$ is the thickness of formation $\mathrm{V}, \mathrm{M}_{\mathrm{fB}}$ is the thickness of formation $\mathrm{B}, \mathrm{M}_{\mathrm{fAB}}$ is the thickness of formation $\mathrm{AB}$, $\mathrm{M}_{\mathrm{fA}}$ is the thickness of formation $\mathrm{A}, \mathrm{M}_{\mathrm{fK} 1}$ is the thickness of formation $\mathrm{K}_{1}, \mathrm{M}_{\mathrm{fK} 2}$ is the thickness of formation $\mathrm{K}_{2}, \mathrm{M}_{\mathrm{fK} 3}$ is the thickness of formation $\mathrm{K}_{3}$.

We compared the distributions using the Student's t-test [11] and Pearson's $\chi^{2}$ test.

The studies consisted in comparing mean values of the indicators and building probability models of pertaining to the class of territories with gas showings (Table 1).

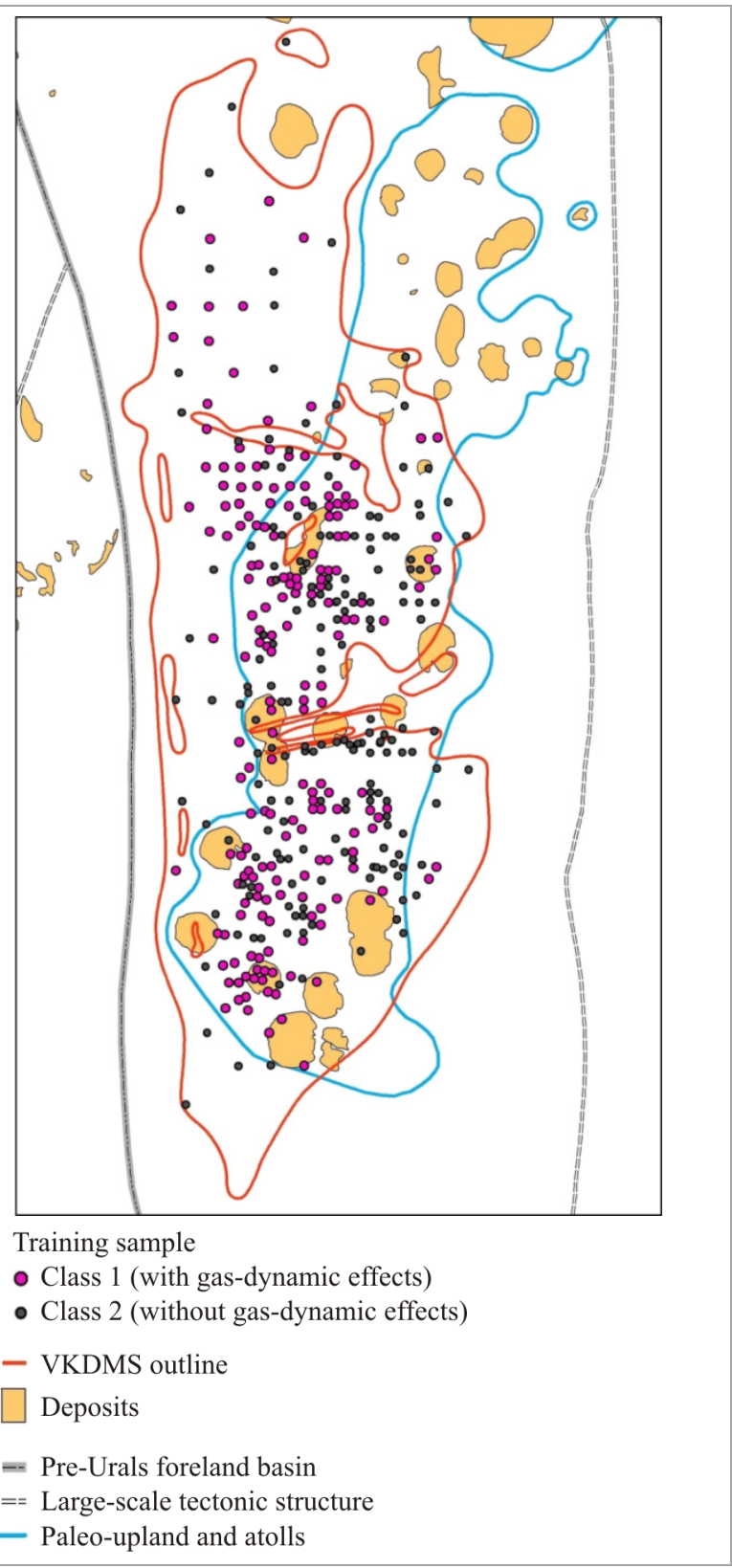

Fig. 1. Well Pattern as per the Gas-dynamic Effects Training Sample 
Table 1

Comparison of Mean Values and Individual Probabilistic Models by Formation Thickness

\begin{tabular}{|c|c|c|c|c|c|c|c|}
\hline \multirow[b]{2}{*}{ Indicator } & \multicolumn{2}{|c|}{ Statistical characteristics of indicators * } & \multicolumn{2}{|c|}{ Criterion } & \multirow[b]{2}{*}{$\begin{array}{l}\text { Probability equation of pertaining } \\
\text { to territory class with gas-show }\end{array}$} & \multirow[b]{2}{*}{$\begin{array}{l}\text { Model } \\
\text { application field }\end{array}$} & \multirow[b]{2}{*}{$\begin{array}{l}\text { Probability } \\
\text { variation range }\end{array}$} \\
\hline & $\begin{array}{c}\text { Class 1. } \\
\text { Territories } \\
\text { with gas-show } \\
(n=187)\end{array}$ & $\begin{array}{c}\text { Class } 2 . \\
\text { Territories } \\
\text { without gas-show } \\
(n=187)\end{array}$ & $\frac{t}{p}$ & $\frac{\chi^{2}}{p}$ & & & \\
\hline $\mathrm{M}_{\mathrm{ors}}, \mathrm{m}$ & $\frac{22.2 \pm 7.1}{0.506 \pm 0.063}$ & $\frac{20.3 \pm 6.5}{0.488 \pm 0.059}$ & $\frac{2.817}{0.005}$ & $\underline{8.585}$ & $P\left(\mathrm{M}_{\mathrm{ors}}\right)=0.306+0.0090 \mathrm{M}_{\mathrm{ors}}$ & $0.5-76.5 \mathrm{~m}$ & $0.31-0.99$ \\
\hline $\mathrm{M}_{\text {potash }}, \mathrm{m}$ & $\frac{78.8 \pm 22.6}{0.531 \pm 0.120}$ & $\frac{64.1 \pm 25.6}{0.453 \pm 0.135}$ & $\frac{5.898}{<10^{-5}}$ & $\frac{34.253}{<10^{-5}}$ & $P\left(\mathrm{M}_{\text {potash }}\right)=0.114+0.0053 \mathrm{M}_{\text {potash }}$ & $0.5-165.8 \mathrm{~m}$ & $0.11-0.99$ \\
\hline$N_{\mathrm{f}}, \mathrm{Nos}$ & $\frac{11.7 \pm 1.8}{0.523 \pm 0.076}$ & $\frac{10.7 \pm 25.6}{0.480 \pm 0.135}$ & $\frac{4.230}{0.00003}$ & $\frac{36.188}{<10^{-5}}$ & $P\left(N_{\mathrm{f}}\right)=0.036+0.04174 N_{\mathrm{f}}$ & $1-13$ items & $0.07-0.58$ \\
\hline $\mathrm{M}_{\mathrm{s}}, \mathrm{m}$ & $\frac{100.0 \pm 23.0}{0.540 \pm 0.124}$ & $\frac{82.0 \pm 27.6}{0.440 \pm 0.151}$ & $\frac{6.845}{<10^{-5}}$ & $\frac{45.835}{<10^{-5}}$ & $P\left(\mathrm{M}_{\mathrm{s}}\right)=0.00+0.540 \mathrm{M}_{\mathrm{s}}$ & $0.5-185.0 \mathrm{~m}$ & $0.00-0.99$ \\
\hline $\mathrm{M}_{\mathrm{fK}}, \mathrm{m}$ & $\underline{0.93 \pm 0.41}$ & $\frac{0.89 \pm 0.40}{0.498 \pm 0.151}$ & $\frac{0.967}{0.334}$ & $\frac{1.931}{0.941}$ & $P\left(\mathrm{M}_{\mathrm{fK}}\right)=0.445+0.06011 \mathrm{M}_{\mathrm{fK}}$ & $0.15-2.80 \mathrm{~m}$ & $0.45-0.61$ \\
\hline $\mathrm{M}_{\mathrm{fl}}, \mathrm{m}$ & $\frac{1.16 \pm 0.63}{0.502 \pm 0.032}$ & $\frac{1.08 \pm 0.60}{0.497 \pm 0.031}$ & $\frac{1.252}{0.211}$ & $\frac{1.895}{<10^{-5}}$ & $P\left(\mathrm{M}_{\mathrm{fl}}\right)=0.441+0.05141 \mathrm{M}_{\mathrm{fl}}$ & $0.07-4.70 \mathrm{~m}$ & $0.44-0.67$ \\
\hline $\mathrm{M}_{\mathrm{fZ}}, \mathrm{m}$ & $\frac{0.58 \pm 0.36}{0.501 \pm 0.013}$ & $\frac{0.62 \pm 0.54}{0.499 \pm 0.018}$ & $\frac{-0.628}{0.530}$ & $\frac{1.404}{0.496}$ & $P\left(\mathrm{M}_{\mathrm{fZ}}\right)=0.521-0.0355 \mathrm{M}_{\mathrm{fZ}}$ & $0.05-7.00 \mathrm{~m}$ & $0.28-0.52$ \\
\hline $\mathrm{M}_{\mathrm{fZh}}, \mathrm{m}$ & $\frac{0.80 \pm 0.47}{0.500 \pm 0.007}$ & $\frac{0.79 \pm 0.35}{0.499 \pm 0.005}$ & $\frac{0.243}{0.809}$ & $\frac{1.125}{0.570}$ & $P\left(\mathrm{M}_{\mathrm{fZh}}\right)=0.487+0.01507 \mathrm{M}_{\mathrm{fZh}}$ & $0.10-4.30 \mathrm{~m}$ & $0.48-0.55$ \\
\hline $\mathrm{M}_{\mathrm{fE}}, \mathrm{m}$ & $\frac{8.82 \pm 5.07}{0.511 \pm 0.069}$ & $\frac{6.68 \pm 4.28}{0.482 \pm 0.005}$ & $\frac{4.401}{0.00001}$ & $\frac{23.412}{<10^{-5}}$ & $P\left(\mathrm{M}_{\mathrm{fE}}\right)=0.391+0.01370 \mathrm{M}_{\mathrm{fE}}$ & $0.20-43.80 \mathrm{~m}$ & $0.39-0.99$ \\
\hline $\mathrm{M}_{\mathrm{fD}}, \mathrm{m}$ & $\frac{9.86 \pm 5.85}{0.511 \pm 0.069}$ & $\frac{7.63 \pm 5.90}{0.482 \pm 0.005}$ & $\frac{3.657}{0.0003}$ & $\frac{16.140}{0.0003}$ & $P\left(\mathrm{M}_{\mathrm{fD}}\right)=0.364+0.01533 \mathrm{M}_{\mathrm{fD}}$ & $0.20-32.25 \mathrm{~m}$ & $0.37-0.90$ \\
\hline $\mathrm{M}_{\mathrm{fG}}, \mathrm{m}$ & $\frac{7.70 \pm 5.24}{0.505 \pm 0.072}$ & $\frac{6.02 \pm 4.26}{0.482 \pm 0.005}$ & $\frac{3.401}{0.0007}$ & $\frac{14.176}{<10^{-5}}$ & $P\left(\mathrm{M}_{\mathrm{fG}}\right)=0.398+0.0139 \mathrm{M}_{\mathrm{fG}}$ & $0.10-43.25 \mathrm{~m}$ & $0.39-0.99$ \\
\hline $\mathrm{M}_{\mathrm{fv}}, \mathrm{m}$ & $\frac{6.69 \pm 3.26}{0.502 \pm 0.012}$ & $\frac{5.28 \pm 3.62}{0.497 \pm 0.014}$ & $\frac{3.947}{0.00009}$ & $\frac{16.670}{<10^{-5}}$ & $P\left(\mathrm{M}_{\mathrm{fv}}\right)=0.476+0.00398 \mathrm{M}_{\mathrm{fv}}$ & $0.15-19.25 \mathrm{~m}$ & $0.47-0.55$ \\
\hline $\mathrm{M}_{\mathrm{fB}}, \mathrm{m}$ & $\frac{2.01 \pm 0.89}{0.501 \pm 0.011}$ & $\frac{1.89 \pm 1.23}{0.499 \pm 0.015}$ & $\frac{0.996}{0.320}$ & $\frac{2.021}{0.364}$ & $P\left(\mathrm{M}_{\mathrm{fB}}\right)=0.476+0.0126 \mathrm{M}_{\mathrm{fB}}$ & $0.15-9.85 \mathrm{~m}$ & $0.47-0.60$ \\
\hline $\mathrm{M}_{\mathrm{fAB}}, \mathrm{m}$ & $\frac{3.64 \pm 1.15}{0.503 \pm 0.026}$ & $\frac{3.36 \pm 1.73}{0.497 \pm 0.040}$ & $\frac{1.798}{0.073}$ & $\frac{4.014}{0.134}$ & $P\left(\mathrm{M}_{\mathrm{fAB}}\right)=0.420+0.02305 \mathrm{M}_{\mathrm{fAB}}$ & $0.42-17.45 \mathrm{~m}$ & $0.42-0.82$ \\
\hline $\mathrm{M}_{\mathrm{fA}}, \mathrm{m}$ & $\frac{1.65 \pm 0.61}{0.503 \pm 0.012}$ & $\frac{1.49 \pm 0.69}{0.499 \pm 0.014}$ & $\frac{2.374}{0.018}$ & $\frac{5.880}{0.0531}$ & $P\left(\mathrm{M}_{\mathrm{fA}}\right)=0.469+0.02113 \mathrm{M}_{\mathrm{fA}}$ & $0.12-12.95 \mathrm{~m}$ & $0.47-0.74$ \\
\hline $\mathrm{M}_{\mathrm{fK} 1, \mathrm{~m}}$ & $\frac{1.14 \pm 0.42}{0.503 \pm 0.025}$ & $\frac{1.04 \pm 0.40}{0.496 \pm 0.024}$ & $\frac{2.717}{0.007}$ & $\frac{6.241}{0.044}$ & $P\left(\mathrm{M}_{\mathrm{fK} 1}\right)=0.435+0.05974 \mathrm{M}_{\mathrm{fK} 1}$ & $0.07-4.20 \mathrm{~m}$ & $0.43-0.68$ \\
\hline $\mathrm{M}_{\mathrm{fK} 2, \mathrm{~m}}$ & $\begin{array}{c}4.64 \pm 1.61 \\
0.501 \pm 0.018\end{array}$ & $\begin{array}{c}\frac{4.51 \pm 1.89}{0.499 \pm 0.021} \\
\end{array}$ & $\frac{0.776}{0.438}$ & $\underline{1.317}$ & $P\left(\mathrm{M}_{\mathrm{fK} 2}\right)=0.447+0.01138 \mathrm{M}_{\mathrm{fK} 2}$ & $0.35-13.35 \mathrm{~m}$ & $0.45-0.59$ \\
\hline $\mathrm{M}_{\mathrm{fK} 3}, \mathrm{~m}$ & $\frac{4.70 \pm 1.92}{0.505 \pm 0.050}$ & $\begin{array}{l}4.27 \pm 2.07 \\
0.494 \pm 0.054\end{array}$ & $\frac{2.068}{0.039}$ & $\frac{4.443}{0.108}$ & $P\left(\mathrm{M}_{\mathrm{fK} 3}\right)=0.382+0.02611 \mathrm{M}_{\mathrm{fK} 3}$ & $0.20-16.25 \mathrm{~m}$ & $0.38-0.78$ \\
\hline
\end{tabular}

Note : $*$ in numerator: mean value \pm standard deviation of the indicator; in denominator: mean value \pm standard deviation of probabilities for this indicator.

These data indicate that the mean values differ statistically for the following indicators: $\mathrm{M}_{\mathrm{or}}, \mathrm{M}_{\text {potash }}$, $\mathrm{N}_{\mathrm{f}}, \mathrm{M}_{\mathrm{s}}, \mathrm{M}_{\mathrm{fE}}, \mathrm{M}_{\mathrm{fD}}, \mathrm{M}_{\mathrm{fG}}, \mathrm{M}_{\mathrm{fV}}$, and $\mathrm{M}_{\mathrm{fA}}$. We built a linear probabilistic models (Table 1) in order to determine the effect of each of the thickness indicators that in different ways control the direction and strength of the gas showing processes. These models made it possible to determine the probability of pertaining to the class of territories where the gas showings occurred, by each indicator.

Building the linear models [12] required initial study of their distributions. For this purpose, the Sturges' formula was used to determine the optimum values of variability intervals for each indicator:

$$
\Delta X=\frac{X_{\max }-X_{\min }}{1+3,32 \cdot \lg N},
$$

where $X_{\max }$ were the maximum value of the indicator; $X_{\min }$ were the minimum value of the indicator; $N$ was the data sampling size.

The frequencies were determined in each interval, as follows:

$$
P(X)=\frac{N_{k}}{N_{g}},
$$

where $P(X)$ were frequency in the k-th interval for the class; $N_{k}$ was the number of cases of the $X$ indicator content in the k-th interval of the class; $N_{g}$ was the sample size for classes 1 and 2 in the k-th interval. 
An example of the distribution by indicator $\mathrm{M}_{\mathrm{s}}$ (thickness of salts) is given in Table 2 .

When comparing distributive densities of the indicators shown in Table 2, the Pearson's $\chi^{2}$ criterion was applied to the classes under study. The criterion values are given in Table 1 . These data indicate that, by the $\chi^{2}$ criterion, 10 out of 18 indicators differ statistically at $p<0.05$.

The technology of linear probabilistic modelling consists in the following.

The probability of pertaining to the territories with gas showings is determined in each interval. The interval probabilities of pertaining to Class 1 are then compared with the mean interval values for the indicators. The obtained values are used to calculate the matching correlation coefficient $r$ and to build a regression equation. The models built are then adjusted on the assumption that the mean value for the territories with gas showings should be greater than 0.5 , and for the territories without gas showings - less than 0.5 . Table 1 contains the regression equations built by this scheme. They are presented by thickness properties and conditions of their application.

Figure 2 provides an example of comparing two individual models by indicators $\mathrm{M}_{\mathrm{fZh}}$ and $\mathrm{M}_{\mathrm{fK} 1}$.

Model $P\left(\mathrm{M}_{\mathrm{fK} 1}\right)$ has a greater value of the angular term in the equation compared to $P\left(\mathrm{M}_{\mathrm{fZh}}\right)$, which leads to more differentiated estimates of the gas showing probability on the VKMKS territory.

The analysis of the individual models and the values of criteria $t$ and $\chi^{2}$ shows that the following indicators are the most informative: $\mathrm{M}_{\text {ors }}, \mathrm{M}_{\text {potash }}$, $N_{\mathrm{f}}, \mathrm{M}_{\mathrm{s}}, \mathrm{M}_{\mathrm{fE}}, \mathrm{M}_{\mathrm{fD}}, \mathrm{M}_{\mathrm{fG}}, \mathrm{M}_{\mathrm{fV}}, \mathrm{M}_{\mathrm{fA}}$, and $\mathrm{M}_{\mathrm{fK} 1}$.

We will apply a stepwise linear discriminant analysis for the complex estimation of probabilities relationship calculated using the linear models for the gas content.

For model development, we used the data from the model sampling that had been utilised to build the linear models (Class 1: 187 values, Class 2: 187 values).

As a result of implementation of this method, the following linear discriminant function was obtained for the formation thicknesses:

$$
\begin{gathered}
Z_{\mathrm{m}}=-17.9265+2.6620 P\left(\mathrm{M}_{\mathrm{s}}\right)-24,1317 P\left(\mathrm{M}_{\mathrm{fB}}\right)+ \\
+13.8526 P\left(\mathrm{M}_{\mathrm{fZ}}\right)+6.2194 P\left(\mathrm{M}_{\mathrm{ors}}\right)+12.6002 P\left(\mathrm{M}_{\mathrm{fK} 1}\right)+ \\
+6.1630 P\left(\mathrm{M}_{\mathrm{fE}}\right)+2.7958 P\left(N_{\mathrm{f}}\right)+3.6734 P\left(\mathrm{M}_{\mathrm{fK} 3}\right)+ \\
+14.8381 P\left(\mathrm{M}_{\mathrm{fV}}\right)+6.7251 P\left(\mathrm{M}_{\mathrm{fK}}\right)-9.3998 P\left(\mathrm{M}_{\mathrm{fK} 2}\right) \\
\text { at } R=0.401, \chi^{2}=63.94120, p<10^{-5} .
\end{gathered}
$$

Table 2

Distribution of $\mathrm{M}_{\mathrm{s}}$ (Thickness of Salt) Value Frequencies

\begin{tabular}{|l|c|c|c|c|c|c|c|c|c|c|}
\hline \multirow{2}{*}{ Territory } & $0-20$ & $\begin{array}{c}20- \\
40\end{array}$ & $\begin{array}{c}40- \\
60\end{array}$ & $\begin{array}{c}60- \\
80\end{array}$ & $\begin{array}{c}80- \\
100\end{array}$ & $\begin{array}{c}100- \\
120\end{array}$ & $\begin{array}{c}120- \\
140\end{array}$ & $\begin{array}{c}140- \\
160\end{array}$ & $\begin{array}{c}160- \\
180\end{array}$ & $\begin{array}{c}180- \\
200\end{array}$ \\
\hline $\begin{array}{l}\text { With gas- } \\
\text { show }\end{array}$ & 0 & 0.005 & 0.032 & 0.112 & 0.336 & 0.347 & 0.133 & 0.026 & 0.005 & 0.005 \\
\hline $\begin{array}{l}\text { Without } \\
\text { gas-show }\end{array}$ & 0.021 & 0.037 & 0.128 & 0.256 & 0.310 & 0.149 & 0.085 & 0.010 & - & - \\
\hline
\end{tabular}

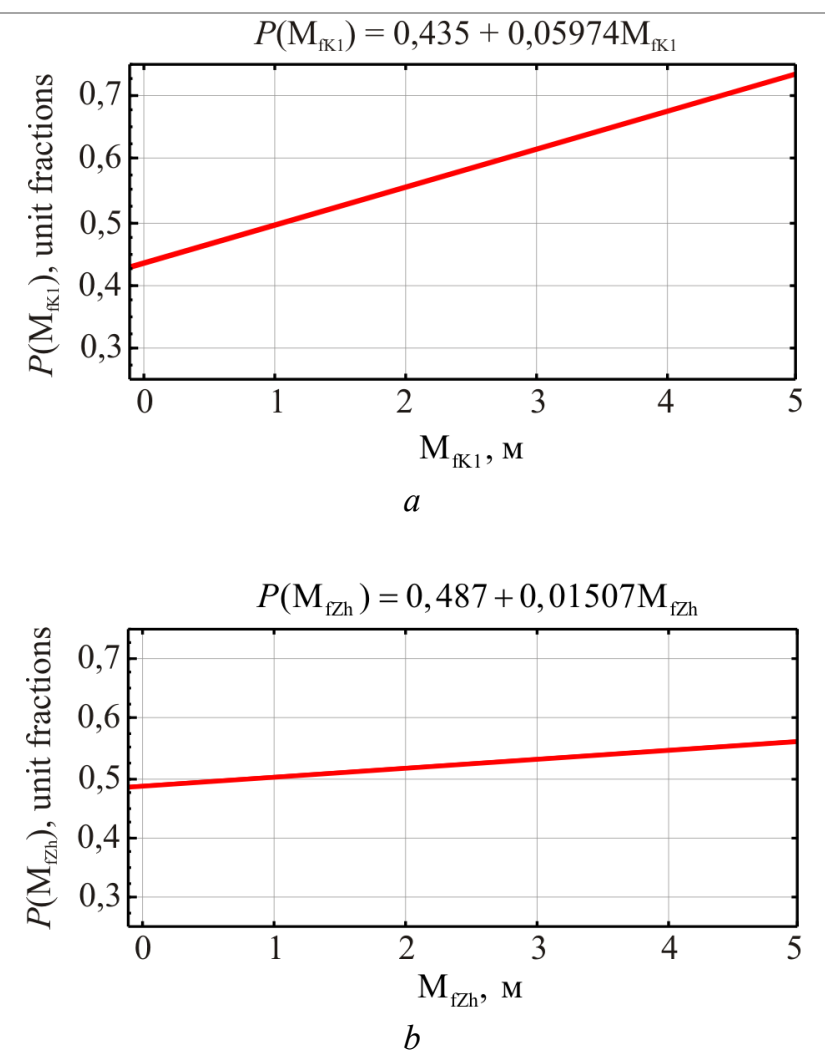

Fig. 2. Comparison of Two Individual Models:

$$
a-P\left(\mathrm{M}_{\mathrm{fK} 1}\right) ; b-P\left(\mathrm{M}_{\mathrm{fZh}}\right)
$$

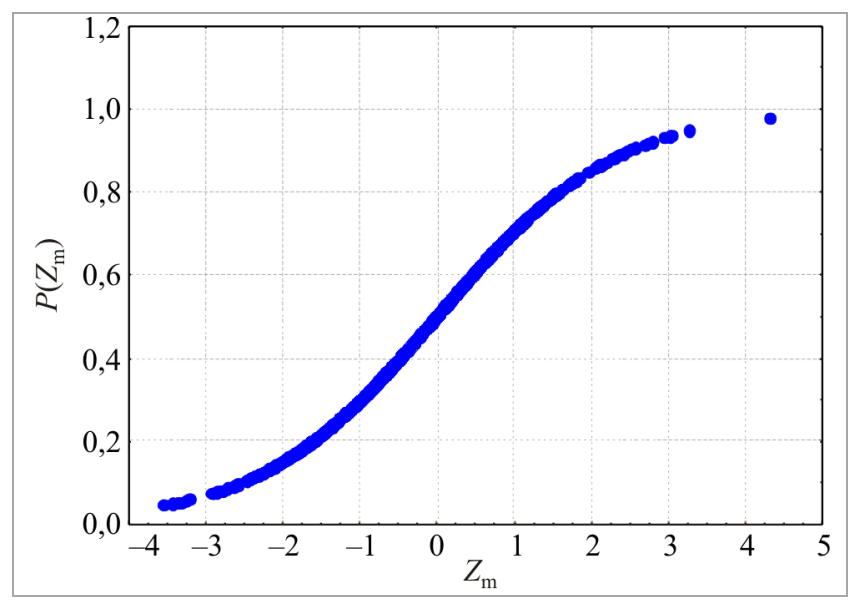

Fig. 3. Dependency of $P\left(Z_{\mathrm{m}}\right)$ on $Z_{\mathrm{m}}$ 
The order of indicators inclusion in the function was formed in the sequence given in the equation.

These functions were used to calculate $Z_{\mathrm{m}}$ values and $P\left(Z_{\mathrm{m}}\right)$ probability. The ratio between $Z_{\mathrm{m}}$ and $P\left(Z_{\mathrm{m}}\right)$ is shown in Figure 3.

\section{Developing the Oil and Gas Potential Prediction Models}

Based on the received $Z_{\mathrm{m}}$ values, the mean (Table 3) values for the wells located within oil and gas bearing outlines (Class $1, n=86$ ) were compared with those for the territories with no determined oil and gas content (class 2, $n=80$ ). The comparison was carried out using the $t$ and $\chi^{2}$ criteria based on a training sample (see Fig. 4) of 166 wells.

The analysis of the $Z_{\mathrm{m}}$ distributions and the probabilistic modelling of pertaining to the class of oil and gas bearing territories were conducted in the same way as with gas showings in the VKDMS strata.

These data indicate that the mean values of $Z_{\mathrm{m}}$ multiple criterion statistically differ from the achieved significance level of $p=0.066$ by the Student's $t$-test. To calculate the probability of pertaining to the class of oil and gas bearing areas, we shall build a linear probabilistic model that enables determining the probability of pertaining to the class of areas with oil and gas content in the section.

To build an oil and gas potential prediction model by $Z_{\mathrm{m}}$ values, we analysed the $Z_{\mathrm{m}}$ distribution by intervals of variability (Table 4 ) for the areas within the oil and gas bearing outline (Class 1) and the ones outside the outline (Class 2).

The distributions of $Z_{\mathrm{m}}$ criterion by intervals of variability are given in Table 4.

Table 3

\section{Comparison of Mean Values}

and Probabilistic Models by $Z_{\mathrm{m}}$ Criterion

\begin{tabular}{|c|c|c|c|c|}
\hline \multirow[b]{2}{*}{ Indicator } & \multicolumn{2}{|c|}{$\begin{array}{l}\text { Statistical characteristics of indicators } \\
\text { (mean value } \pm \text { standard deviation) }\end{array}$} & \multirow[b]{2}{*}{$\frac{t}{p}$} & \multirow[b]{2}{*}{$\frac{\chi^{2}}{p}$} \\
\hline & $\begin{array}{c}\text { Class } 1 . \\
\text { Within oil and gas } \\
\text { bearing outline } \\
(n=86)\end{array}$ & $\begin{array}{c}\text { Class } 2 . \\
\text { Outside oil and gas } \\
\text { bearing outline } \\
(n=80)\end{array}$ & & \\
\hline$Z_{\mathrm{m}}$ & $-0.763 \pm 1.085$ & $-0.449 \pm 1.113$ & $\frac{1.841}{0.066}$ & $\frac{3.344}{0.019}$ \\
\hline
\end{tabular}

Table 4

Frequency Distribution of $Z_{\mathrm{m}}$ Values

\begin{tabular}{|l|c|c|c|c|c|c|c|}
\hline \multirow{2}{*}{ Class } & \multicolumn{7}{|c|}{$Z_{\mathrm{m}}$ variability intervals } \\
\cline { 2 - 8 } & $\begin{array}{c}(-4.5 ; \\
-3.5]\end{array}$ & $\begin{array}{c}(-3.5 ; \\
-2.5]\end{array}$ & $\begin{array}{c}(-2.5 ; \\
-1.5]\end{array}$ & $\begin{array}{c}(-1.5 ; \\
-0.5]\end{array}$ & $\begin{array}{c}(-0.5 ; \\
0.5]\end{array}$ & $\begin{array}{c}0.5 ; \\
1.5]\end{array}$ & $\begin{array}{c}(1.5 ; \\
-2.5]\end{array}$ \\
\hline $\begin{array}{l}\text { Within oil and } \\
\text { gas bearing } \\
\text { outline }\end{array}$ & 0 & 0.046 & 0.267 & 0.244 & 0.337 & 0.081 & 0.025 \\
\hline $\begin{array}{l}\text { Outside oil and } \\
\text { gas bearing } \\
\text { outline }\end{array}$ & 0.014 & 0.037 & 0.087 & 0.350 & 0.300 & 0.175 & 0.037 \\
\hline
\end{tabular}
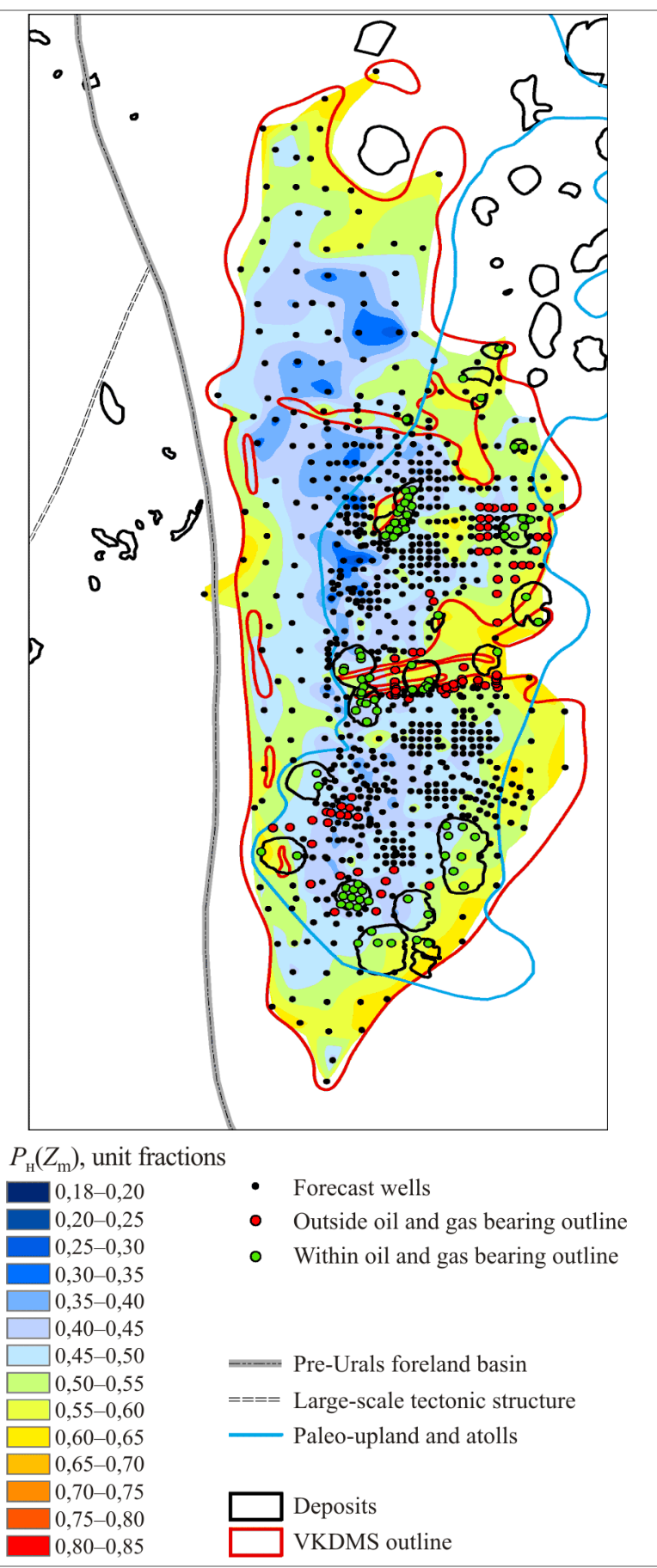

Fig. 4. Scheme of $P_{\mathrm{p}}\left(Z_{\mathrm{m}}\right)$ Variation in the VKDMS Territory 
According to the data in Table 4, the frequency for Class 1 in the interval $(-0.5 ; 0.5)$ is 0.337 unit fractions, and 0.300 unit fractions for Class 2. When comparing the $Z_{\mathrm{m}}$ distribution densities as shown in Table 4 , the Pearson's $\chi^{2}$ criterion was applied to the classes under study.

The values of $\chi^{2}$ criterion are shown in Table 3 . These data indicate that the $Z_{\mathrm{m}}$ distributions statistically differ by $\chi^{2}$ criterion at $p=0.019$.

In order to build a linear probabilistic model of oil and gas potential prediction based on the gas showings data for the VKDMS strata, the probabilities of pertaining to oil and gas bearing territories are determined in each interval of variability. The interval probabilities of pertaining to Class 1 are then compared with the mean interval values of $Z_{\mathrm{m}}$ complex criterion. These values are used to calculate the matching correlation coefficient $r$, and to build a regression equation. The obtained models are then adjusted on the assumption that the mean value of $P_{\mathrm{p}}\left(Z_{\mathrm{m}}\right)$ for the oil and gas bearing territories should be greater than 0.5 , and for the territories outside the oil and gas content outline - less than 0.5 .

The following model of oil and gas potential probability prediction using $Z_{\mathrm{m}}$ data was obtained:

$$
P_{\mathrm{p}}\left(Z_{\mathrm{m}}\right)=0.462-0.0635 Z_{\mathrm{m}}, r=-0.67 \text {. }
$$

The $Z_{\mathrm{m}}$ model's application range varies from 3.525 to 2.205 . With the increase of $Z_{\mathrm{m}}$ values from negative to positive, $P_{\mathrm{p}}\left(Z_{\mathrm{m}}\right)$ decreases from 0.682 to 0.321 unit fractions. Using this dependency, $P_{\mathrm{p}}\left(Z_{\mathrm{m}}\right)$ values were calculated for all 856 studied wells drilled for exploration and prospecting salt extraction operations.

\section{Conclusion}

In the result, the obtained mean values of the developed criterion $P_{\mathrm{p}}\left(Z_{\mathrm{m}}\right)$ indicate that it can be used for a zonal estimate of oil and gas content in the territory under study. The mean value of the oil and gas content probability $P_{\mathrm{p}}\left(Z_{\mathrm{m}}\right)$ for the areas within the oil and gas bearing outline was $0.510 \pm$ 0.068 unit fractions; and $0.490 \pm 0.070$ unit fractions for the ones outside the oil and gas bearing outline.

The calculated $P_{\mathrm{p}}\left(Z_{\mathrm{m}}\right)$ values were used to build a scheme of oil and gas content probability for the research area (Fig. 4).

In the scheme, the probabilities $P_{\mathrm{p}}\left(Z_{\mathrm{m}}\right)>0.5$ characterise the peripheral parts of the VKDMS, the $P_{\mathrm{p}}\left(Z_{\mathrm{m}}\right)$ values $<0.5$ are in the central part of the VKDMS. The developed scheme can be used in planning geological exploration operations for oil production in the VKDMS territory.

\section{References}

1. Galkin V.I., Rastegaev A.V., Kozlova I.A., Galkin S.V., Merson M.E. Geologo-matematicheskaia otsenka vliianiia solei na protsessy neftegazogeneratsii (na primere Solikamskoi depressii) [Geological and mathematical assessment of salt influence on oil and gas generation processes (on the example of Solikamsk depression)]. Izvestiia vysshikh uchebnykh zavedenii. Neft i gaz, 2003, no.6, pp.9-13.

2. Bakharev P.N. Blokovoe stroenie i neftegazonosnost severa Solikamskoi depressii [Block structure and oil and gas potential of the north of the Solikamsk depression]. Geologiia $i$ razvedka nefti i gaza; Permskii politekhnicheskii universitet. Perm, 1989, pp.8-15.

3. Voevodkin V.L., Galkin V.I., Kozlova I.A., Krivoshchekov S.N., Kozlov A.S. O masshtabakh migratsii uglevodorodov $\mathrm{v}$ predelakh Solikamskoi depressii preduralskogo progiba i vozmozhnostiakh ee ispolzovaniia dlia prognoza neftegazonosnosti
[Hydrocarbons migration volumes within the limits of Solikamsk depression (Pre-Ural deflection) and possibilities of its use for the oil and gas content forecast]. Geologiia, geofizika i razrabotka neftianykh $i$ gazovykh mestorozhdenii, 2010, no.12, pp.6-11.

4. Galkin V.I., Kozlova I.A., Galkin S.V., Rastegaev A.V., Melkomukov V.V. Zonalno-lokalnaia otsenka perspektiv neftegazonosnosti Solikamskoi depressii [Zonal-local forecast oil-and-gas content at Solikamsk depression]. Geology, geophysics and development of oil and gas fields, 2007, no.10, pp.8-11.

5. Galkin V.I., Kozlova I.A., Rastegaev A.V., Vantseva I.V., Krivoshchekov S.N., Voevodkin V.L. $\mathrm{K}$ metodike otsenki perspektiv neftegazonosnosti Solikamskoi depressii po kharakteristikam lokalnykh struktur [On the methodology for assessing the prospects of oil and gas potential of the Solikamsk depression according to the characteristics of local structures]. Oilfield engineering, 2010, no.7, pp.12-17. 
6. Galkin V.I., Melkishev O.A. Razrabotka zonalnykh veroiatnostno-statisticheskikh modelei prognoza neftegazonosnosti dlia verkhnevizeisko-bashkirskogo karbonatnogo neftegazonosnogo kompleksa na territorii Solikamskoi depressii [Development of zonal probabilistic and statistical models of oil and gas forecast for the Upper Visean-Bashkir carbonate oil and gas complex in the territory of the Solikamsk depresssion]. Novye idei v geologii nefti i gaza, 2017, pp.58-63.

7. Sharonov L.V. Formirovanie neftianykh i gazovykh mestorozhdenii severnoi chasti volgo-uralskogo basseina [Formation of oil and gas fields in the northern part of the Volga-Ural basin]. Perm, 1971, 287 p.

8. Kozlova I.A., Galkin V.I., Vantseva I.V. $\mathrm{K}$ otsenke perspektiv neftegazonosnosti solikamskoi depressii s pomoshchiu generatsionno-dinamicheskikh kharakteristik neftegazomaterinskikh porod [Evaluation of Solikamsk depression petroleum potential based on generation-dynamic characteristics of oil and gas source rocks]. Oilfield engineering, 2010, no.7, pp.24-27.

9. Kozlova I.A., Galkin V.I., Vantseva I.V. K otsenke perspektiv neftegazonosnosti Solikamskoi depressii s pomoshchiu geologo-geokhimicheskikh kharakteristik neftegazomaterinskikh porod [Evaluation of Solikamsk depression petroleum potential based on geological and geochemical characteristics of oil and gas source rocks]. Oilfield engineering, 2010, no.7, pp.20-23.

10. Liadova N.A., Iakovlev Iu.A., Raspopov A.V. Geologiia i razrabotka neftianykh mestorozhdenii permskogo kraia [Geology and development of oil fields of the Perm region]. Moscow, VNIIOENG, 2010, 335 p.

11. Galkin V.I., Kozlova I.A., Krivoshchekov S.N., Melkishev O.A. K obosnovaniiu postroeniia modelei zonalnogo prognoza neftegazonosnosti dlia nizhnesrednevizeiskogo kompleksa Permskogo kraia [On the justification of the construction of models for oil and gas potential area forecast Visean deposits of Perm region]. Oil industry, 2015, no.8, pp.32-35.

12. Galkin V.I., Rastegaev A.V., Kozlova I.A., Vantseva I.V., Krivoshchekov S.N., Voevodkin B.L. Prognoznaia otsenka neftegazonosnosti struktur na territorii Solikamskoi depressii [Probable estimation of oil content of structures in territory of Solikamsk depression]. Oilfield engineering, 2010, no.7, pp.4-7.

13. Krivoshchekov S.N., Galkin V.I., Kozlova I.A. Determination of potentially oil bearing areas by behavioristical method by the example of Perm region (krai). Perm Journal of Petroleum and Mining Engineering, 2012, no.4, pp.7-14.
14. Putilov I.O., Galkin V.I. Primenenie veroiatnostnogo statisticheskogo analiza dlia izucheniia fatsialnoi zonalnosti turne-famenskogo karbonatnogo kompleksa Sibirskogo mestorozhdeniia [The results of statistical analysis for study fades characterization of T-Fm stage of Sibirskoe oilfield]. Oil industry, 2007, no.9, pp.112-114.

15. Devis Dzh.S. Statisticheskii analiz dannykh v geologii [The statistical analysis of data in geology]. Moscow, Nedra, book 1, 319 p.; book 2, 427 p.

16. Chini R.F. Staticheskie metody v geologii [Static methods in geology]. Moscow, Mir, 1986, $189 \mathrm{p}$.

17. Sharapov I.P. Primenenie matematicheskoi statistiki v geologii. Statisticheskii analiz geologicheskikh dannykh [Application of mathematical statistics in geology. Statistical analysis of geological data]. Moscow, Nedra, 1971, 246 p.

18. Porotov G.S. Matematicheskie metody modelirovaniia $\mathrm{v}$ geologii [Mathematical methods of modeling in geology]. Saint Petersburg, Izdatelstvo Sankt-Peterburgskogo gosudarstvennogo gornogo instituta (tekhnicheskogo universiteta), 2006, $223 \mathrm{p}$.

19. Mikhalevich I.M. Primenenie matematicheskikh metodov pri analize geologicheskoi informatsii (s ispolzovaniem kompiuternykh tekhnologii: Statistica) [Application of mathematical methods in the analysis of geological information (with use of computer technologies: Statistica)]. Irkutsk, IGU, 2006, 115 p.

20. Dementev L.F. Matematicheskie metody i EVM v neftegazovoi geologii [Mathematical methods and the COMPUTER in oil and gas geology]. Moscow, Nedra, 1987, 264 p.

21. Davydenko A.Iu. Veroiatnostno-statisticheskie metody $\mathrm{v}$ geologo-geofizicheskikh prilozheniiakh [Probabilistic and statistical methods in geologicgeophysical applications]. Irkutsk, 2007, 29 p.

22. Koshkin K.A., Melkishev O.A. Use of derivatives to assess preservation of hydrocarbon deposits. International Conference Information Technologies in Business and Industry. Tomsk, 2018, vol.1015, pp.032092.

23. Houze O., Viturat D., Fjaere O.S. Dinamie data analysis. Paris, Kappa Engineering, 2008, 694 p.

24. Van Golf-Racht T.D. Fundamentals of fractured reservoir engineering. Amsterdam, Oxford, New York, Elsevier scientific publishing company, 1982, 709 p.

25. Horne R.N. Modern well test analysis: a computer aided approach. 2nd ed. Palo Alto, PetrowayInc, 2006, 257 p. 
26. Johnson N.L., Leone F.C. Statistics and experimental design. New York, London, Sydney, Toronto, 1977, $606 \mathrm{p}$.

27. Montgomery D.C., Peck E.A. Introduction to liner regression analysis. New York, John Wiley \& Sons, 1982, $504 \mathrm{p}$.

28. Darling T. Well logging and formation evalution. GardnersBooks, 2010, 336 p.

29. Watson G.S. Statistic on spheres. New York, John Wiley and Sons, Inc., 1983, 238 p.

30. Yarus J.M. Stochastic modeling and geostatistics. AAPG. Tulsa, Oklahoma, 1994, 231 p.

31. Andreiko S.S., Lialina T.A. Issledovaniia gazovydelenii iz geologorazvedochnykh skvazhin na Verkhnekamskom mestorozhdenii kaliinykh solei [The analysis of gas emission out of geologic prospecting wells at Verkhnekamskoye deposit of potassium salts]. News of the Higher Institutions. Mining Journal, 2017, no.2, pp.33-38.

32. Andreiko S.S., Ivanov O.V., Nesterov E.A. Borba $\mathrm{S}$ gazodinamicheskimi iavleniiami pri razrabotke Verkhnekamskogo i Starobinskogo mestorozhdenii kaliinykh solei [Fight against the gasdynamic phenomena when developing Verkhnekamsky and Starobinsky fields of potash salts]. Nauchnye issledovaniia i innovatsii: nauchnyi zhurnal, 2010, vol.3, no.4.

33. Andreiko S.S., Kalugin P.A., Shcherba V.Ia. Gazodinamicheskie iavleniia v kaliinykh rudnikakh: genezis, prognoz i upravlenie [The gasdynamic phenomena in potash mines: genesis, forecast and management]. Minsk, Vysshaia shkola, 2000.

34. Andreiko S.S. Gazodinamicheskie iavleniia $\mathrm{v}$ kaliinykh rudnikakh: metody prognoza i sposoby predotvrashcheniia [The gasdynamic phenomena in potash mines: methods of the forecast and ways of prevention: studies grant]. Perm, Izdatelstvo Permskogo gosudarstvennogo tekhnicheskogo universiteta, 2007.

35. Andreiko S.S. Mekhanizm obrazovaniia ochagov gazodinamicheskikh iavlenii $\mathrm{v}$ solianom porodnom massive [Mekhanizm of formation of the centers of the gasdynamic phenomena in hydrochloric rock mass]. Perm, Izdatelstvo Permskogo gosudarstvennogo tekhnicheskogo universiteta, 2008.

36. Andreiko S.S., Ivanov O.V., Kharintsev A.V., Chistiakov A.N. Prognozirovanie vybrosoopasnykh zon plastov pri razvedke i razrabotke Verkhnekamskogo mestorozhdeniia kaliinykh solei [Forecasting of the combustion zones of layers at exploration and development of the Verkhnekamsky field of potash salts]. Gornyi zhurnal, 2008, no.10.

37. Andreiko S.S., Ivanov O.V., Litvinovskaia N.A. Prognozirovanie i predotvrashchenie gazodinamicheskikh iavlenii iz pochvy pri prokhodke podgotovitelnykh vyrabotok $\mathrm{v}$ podrabotannom massive solianykh porod [Forecasting and prevention of the gasdynamic phenomena from the soil at a driving of preparatory developments in the earned additionally massif of salt breeds]. Perm, Izdatelstvo Permskogo natsionalnogo issledovatelskogo politekhnicheskogo universiteta, 2015.

38. Andreiko S.S., Bashura A.N., Shcherba V.Ia. Upravlenie gazodinamicheskimi protsessami pri podzemnoi razrabotke Starobinskogo mestorozhdeniia kaliinykh solei [Management of gasdynamic processes by underground mining of the Starobinsky field of potash salts]. Moscow, Izdatelstvo MGGU, 2004.

39. Andreiko S.S. Gazovydeleniia pri burenii geologo-razvedochnykh skvazhin na Verkhnekamskom mestorozhdenii [Gas emission when drilling prospecting wells on the Verkhnekamsky field]. Aeropylegazodinamika gornykh vyrabotok, 1987.

40. Proskuriakov N.M. Vnezapnye vybrosy porody i gaza $\mathrm{v}$ kaliinykh rudnikakh [Sudden emissions of breed and gas in potash mines]. Moscow, Nedra, 1980.

41. Proskuriakov N.M. Upravlenie gazodinamicheskimi protsessami $\mathrm{v}$ plastakh kaliinykh rud [Control of gas-dynamic processes in potash ore beds]. Moscow, Nedra, 1988, 239 p.

42. Kudriashov A.I. Verkhnekamskoe mestorozhdenie solei [Verkhnekamskoe salt field]. Perm, GI UrO RAN, 2001, 429 p.

43. Kudriashov A.I. Verkhnekamskoe mestorozhdenie solei [Verkhnekamskoe salt field, 2nd ed., Revised]. Moscow, Epsilon Plius, 2013, 368 p.

44. Kudriashov A.I., Andreiko S.S. O prirode ochagov vnezapnykh vybrosov soli i gaza [On the nature of foci of sudden release of salt and gas]. News of the Higher Institutions. Mining Journal, 1986, no.2, pp.10-11.

45. Andreiko S.S. Statisticheskie kriterii i rezultaty otsenki zakonomernostei raspredeleniia gazodinamicheskikh iavlenii na kaliinykh mestorozhdeniiakh [Statistical criteria and results of the assessment of patterns of distribution of gasdynamic phenomena in potash deposits]. Fizikotekhnicheskie problemy razrabotki poleznykh iskopaemykh, 2003, no.4, pp.45-55. 


\section{Список литературы}

1. Геолого-математическая оценка влияния солей на процессы нефтегазогенерации (на примере Соликамской депрессии) / В.И. Галкин, А.В. Растегаев, И.А. Козлова, С.В. Галкин, М.Э. Мерсон // Известия высших учебных заведений. Нефть и газ. 2003. - № 6. - C. 9-13.

2. Бахарев П.Н. Блоковое строение и нефтегазоносность севера Соликамской депрессии // Геология и разведка нефти и газа / Перм. политехн. ун-т. - Пермь, 1989. - С. 8-15.

3. О масштабах миграции углеводородов в пределах Соликамской депрессии Предуральского прогиба и возможностях ее использования для прогноза нефтегазоносности / В.Л. Воеводкин, В.И. Галкин, И.А. Козлова, С.Н. Кривощеков, А.С. Козлов // Геология, геофизика и разработка нефтяных и газовых месторождений. - 2010. - № 12. - С. 6-11.

4. Зонально-локальная оценка перспектив нефтегазоносности Соликамской депрессии / В.И. Галкин, И.А. Козлова, С.В. Галкин, А.В. Растегаев, В.В. Мелкомуков // Геология, геофизика и разработка нефтяных и газовых месторождений. - 2007. - № 10. - С. 8-11.

5. К методике оценки перспектив нефтегазоносности Соликамской депрессии по характеристикам локальных структур / В.И. Галкин, И.А. Козлова, А.В. Растегаев, И.В. Ванцева, С.Н. Кривощеков, В.Л. Воеводкин // Нефтепромысловое дело. - 2010. - № 7. - С. 12-17.

6. Галкин В.И., Мелкишев О.А. Разработка зональных вероятностно-статистических моделей прогноза нефтегазоносности для верхневизейско-башкирского карбонатного нефтегазоносного комплекса на территории Соликамской депрессии // Новые идеи в геологии нефти и газа. - 2017. - С. 58-63.

7. Шаронов Л.В. Формирование нефтяных и газовых месторождений северной части ВолгоУральского бассейна. - Пермь, 1971. - 287 с.

8. Козлова И.А., Галкин В.И., Ванцева И.В. К оценке перспектив нефтегазоносности Соликамской депрессии с помощью генерационно-динамических характеристик нефтегазоматеринских пород // Нефтепромысловое дело. - 2010. - № 7. - С. 24-27.

9. Козлова И.А., Галкин В.И., Ванцева И.В. К оценке перспектив нефтегазоносности Соликамской депрессии с помощью геолого-геохимических характеристик нефтегазоматеринских пород // Нефтепромысловое дело. - 2010. - № 7. - С. 20-23.
10. Лядова Н.А., Яковлев Ю.А., Распопов А.В. Геология и разработка нефтяных месторождений Пермского края. - М.: ВНИИОЭНГ, 2010. - 335 с.

11. К обоснованию построения моделей зонального прогноза нефтегазоносности для нижне- и средневизейского комплекса Пермского края / В.И. Галкин, И.А. Козлова, С.Н. Кривощеков, О.А. Мелкишев // Нефтяное хозяйство. - 2015. - № 8. - С. 32-35.

12. Прогнозная оценка нефтегазоносности структур на территории Соликамской депрессии / В.И. Галкин, А.В. Растегаев, И.А. Козлова, И.В. Ванцева, С.Н. Кривощеков, В.Л. Воеводкин // Нефтепромысловое дело. - 2010. - № 7. - С. 4-7.

13. Кривощеков С.Н., Галкин В.И., Козлова И.А. Определение перспективных участков геолого-разведочных работ на нефть вероятностно-статистическими методами на примере территории Пермского края // Вестник Пермского национального исследовательского политехнического университета. Геология. Нефтегазовое и горное дело. - 2012. - № 4. - С. 7-14.

14. Путилов И.О., Галкин В.И. Применение вероятностного статистического анализа для изучения фациальной зональности турне-фаменского карбонатного комплекса Сибирского месторождения // Нефтяное хозяйство. - 2007. - № 9. - С. 112-114.

15. Дэвис Дж.С. Статистический анализ данных в геологии: пер. с англ. - М.: Недра, 1990. - Кн. $1-319$ с.; кн. 2. -427 с.

16. Чини Р.Ф. Статические методы в геологии: пер. с англ. - М.: Мир, 1986. - 189 с.

17. Шарапов И.П. Применение математической статистики в геологии. Статистический анализ геологических данных. - М.: Недра, 1971. - 246 с.

18. Поротов Г.С. Математические методы моделирования в геологии. - СПб.: Изд-во СанктПетербур. гос. горн. ин-та (техн. ун-та), 2006. - 223 с.

19. Михалевич И.М. Применение математических методов при анализе геологической информации (с использованием компьютерных технологий: Statistica) / ИГУ. - Иркутск, 2006. - 115 с.

20. Дементьев Л.Ф. Математические методы и ЭВМ в нефтегазовой геологии. - М.: Недра, 1987. - 264 c.

21. Давыденко А.Ю. Вероятностно-статистические методы в геолого-геофизических приложениях. - Иркутск, 2007. - 29 с.

22. Koshkin K.A., Melkishev O.A. Use of derivatives to assess preservation of hydrocarbon deposits // 
International Conference Information Technologies in Business and Industry. - Tomsk, 2018. - Vol. 1015. - P. 032092.

23. Houze O., Viturat D., Fjaere O.S. Dinamie data analysis. - Paris: Kappa Engineering, 2008. - 694 p.

24. Van Golf-Racht T.D. Fundamentals of fractured reservoir engineering / Elsevier scientific publishing company. - Amsterdam-Oxford-New York, 1982. - 709 p.

25. Horne R.N. Modern well test analysis: a computer aided approach. - 2nd ed. - Palo Alto: Petroway Inc, 2006. - 257 p.

26. Johnson N.L., Leone F.C. Statistics and experimental design. - New York - London - Sydney Toronto, 1977. $-606 \mathrm{p}$.

27. Montgomery D.C., Peck E.A. Introduction to liner regression analysis. - New York: John Wiley \& Sons, 1982. $-504 \mathrm{p}$.

28. Darling T. Well logging and formation evalution. - Gardners Books, 2010. - 336 p.

29. Watson G.S. Statistic on spheres. - New York: John Wiley and Sons, Inc., 1983. - 238 p.

30. Yarus J.M. Stochastic modeling and geostatistics // AAPG. - Tulsa, Oklahoma, 1994. - 231 p.

31. Андрейко С.С., Лялина Т.А. Исследования газовыделений из геолого-разведочных скважин на Верхнекамском месторождении калийных солей // Известия вузов. Горный журнал. - 2017. - № 2. - С. 33-38.

32. Андрейко С.С., Иванов О.В., Нестеров Е.А. Борьба с газодинамическими явлениями при разработке Верхнекамского и Старобинского месторождений калийных солей // Научные исследования и инновации. - 2010. - Т. 3, № 4. - С. 34-37.

33. Андрейко С.С., Калугин П.А., Щерба В.Я. Газодинамические явления в калийных рудниках: генезис, прогноз и управление. - Минск: Вышэйшая школа, 2000. - 335 с.

34. Андрейко С.С. Газодинамические явления в калийных рудниках: методы прогноза и способы предотвращения: учеб пособие. - Пермь: Изд-во Перм. гос. техн. ун-та, 2007. -219 с.

35. Андрейко С.С. Механизм образования очагов газодинамических явлений в соляном породном массиве. - Пермь: Изд-во Перм. гос. техн. ун-та, 2008. - 196 с.

36. Прогнозирование выбросоопасных зон пластов при разведке и разработке Верхнекамского месторождения калийных солей / С.С. Андрейко, О.В. Иванов, А.В. Харинцев, А.Н. Чистяков // Горный журнал. - 2008. - № 10. - С. 34-37.

37. Андрейко С.С., Иванов О.В., Литвиновская Н.А. Прогнозирование и предотвращение газодинамических явлений из почвы при проходке подготовительных выработок в подработанном массиве соляных пород. - Пермь: Изд-во Перм. нац. исслед. политехн. ун-та, 2015. - 158 с.

38. Андрейко С.С., Башура А.Н., Щерба В.Я. Управление газодинамическими процессами при подземной разработке Старобинского месторождения калийных солей. -М.: Изд-во МГГУ, 2004. - 196 с.

39. Андрейко С.С. Газовыделения при бурении геолого-разведочных скважин на Верхнекамском месторождении // Аэропылегазодинамика горных выработок: сб. науч. тр.; Ленингр. геол. ин-т. - Л., 1987. - С. 49-54.

40. Проскуряков Н.М. Внезапные выбросы породы и газа в калийных рудниках. М.: Недра, 1980. - 263 с.

41. Проскуряков Н.М. Управление газодинамическими процессами в пластах калийных руд. - М.: Недра, 1988. - 239 с

42. Кудряшов А.И. Верхнекамское месторождение солей. - Пермь: ГИ УрО РАН, 2001. - 429 с

43. Кудряшов А.И. Верхнекамское месторождение солей. - 2-е изд., перераб. - М.: Эпсилон Плюс, 2013. $-368 \mathrm{c}$.

44. Кудряшов А.И., Андрейко С.С. О природе очагов внезапных выбросов соли и газа // Известия вузов. Горный журнал. - 1986. - № 2. - С. 10-11.

45. Андрейко С.С. Статистические критерии и результаты оценки закономерностей распределения газодинамических явлений на калийных месторождениях // Физико-технические проблемы разработки полезных ископаемых. - 2003. - № 4. - С. 45-55.

Please cite this article in English as:

Galkin V.I., Melkishev O.A., Varushkin S.V., Andreiko S.S., Lialina T.A. Developing a statistical model of oil and gas potential prediction by gas showings in the Verkhnekamskoye deposit strata of potassium and magnesium salts. Perm Journal of Petroleum and Mining Engineering, 2020, vol.20, no.1, pp.4-13. DOI: 10.15593/2224-9923/2020.1.1

Просьба ссылаться на эту статью в русскоязычных источниках следующим образом:

Разработка статистической модели прогноза нефтегазоносности по газовыделениям в толще Верхнекамского месторождения калийно-магниевых солей / В.И. Галкин, О.А. Мелкишев, С.В. Варушкин, С.С. Андрейко, Т.А. Лялина // Вестник Пермского национального исследовательского политехнического университета. Геология. Нефтегазовое и горное дело. - 2020. - Т.20, №1. - C.4-13. DOI: 10.15593/2224-9923/2020.1.1 